TAO, Vol. 13, No. 3, 375-386, September 2002

\title{
An Electric Resistivity Study of the Chelungpu Fault in the Tsaotun Area, Central Taiwan
}

\author{
Ping-Hu Cheng ${ }^{1, *}$, Chieh-Hou Yang ${ }^{2}$, Jiunn-I You ${ }^{1}$, and Jyh-Shyan Shieh ${ }^{1}$
}

(Manuscript received 29 March 2002, in final form 8 July 2002)

\begin{abstract}
We conducted an electric resistivity survey in the Tsaotun area to investigate the subsurface structures of the complex deformation and rupture of Chelungpu fault system induced by the 1999 Chi- Chi earthquake. Four electric resistivity image profiles with pole-pole array across fault zones and topographic lineation were conducted in this survey. The sounding data were interpreted by the $2-D$ inversion method.

The results show that the electric resistivity structures interpreted from the resistivity sounding data fit well with ruptures and outcrops appeared on the ground surface. We also evaluated the resistivity ranges for different formations, the top layer thickness and the width of the fault zones.

Resistivity-layer discontinuities found on the profiles correlate to the fault zones of the Chelungpu fault and the back thrust. The boundary between the Toukoshan Formation and the Chinshui Shale is the characteristic contact of the Chelungpu fault. It is a reverse fault including several fracture zones in the Tsaotun area. Some ruptures developed in weaker layers of the Chinshui Shale have been active since the deposition of the Quaternary terrace gravel bed. The main fracture zones have a width of 6 $40 \mathrm{~m}$ and dip eastward at an angle of $80^{\circ}-30^{\circ}$ that decrease with depth. The fault diverged into $V$-shape fractures or more branches near the ground surface in some regions. Not all the fractures of the Chelungpu fault system moved during the Chi-Chi earthquake, but they were active previously.
\end{abstract}

(Key words: Electric resistivity, Chelungpu fault, Tsaotun)

\section{INTRODUCTION}

The Tsaotun area is about $16 \mathrm{~km}$ northwest of Chi-chi, the epicenter of a large earthquake occurred on September 21, 1999 in central Taiwan (Fig.1). The earthquake accompanied ex-

\footnotetext{
${ }^{1}$ Institute of Geophysics, National Central University, Chung-Li, Taiwan

${ }^{2}$ Ching-Yun institute of Technology, Chung-Li, Taiwan

* Corresponding author address: Prof. Ping-Hu Cheng, Institute of Geophysics, National Central University, Chung-Li, Taiwan; E-mail: huh@geps.gep.ncu.edu.tw
} 
tensive surface ruptures of about $100 \mathrm{~km}$ long in central Taiwan. The major ruptures appeared along the Chelungpu fault trending N-S between Fongyuan in the north and Chushan in the south, and a new branch trending NEE started from Fongyuan to Cholan at the north tip of the Chelungpu fault system(Lee et al. 1999; Cheng 2000).

The Chelungpu fault is a thrust fault as indicated by the older Pliocene formations, the Chinshui Shale and the Cholan Formation on the hanging wall while the younger Quaternary formations, the Toukoshan Formation and the Alluvium on the footwall (Lin 1957; Meng 1963; Chang et al. 1998; Lin et al. 2000). The fault plane was suggested to be east dipping at an angle between $15^{\circ}$ and $40^{\circ}$, indicated by gravity and seismic studies (Pan 1967; Chang 1971).

Before the 1999 Chi-Chi earthquake, only a few outcrops of the Chelungpu fault were found and most part of the faultline could not be traced due to weathering, collapsing, and debris coverage. During the 1999 Chi-Chi earthquake, the Chelungpu fault was reactivated with the hanging wall lifted about 1-4 meters above the footwall (Chang et al. 1999; Lee et al. 1999). The surface ruptures showed that the fault is a more complex system than previous model suggested, especially in the Tsaotun area where we can see 2-3 large fault scarps with a few fractures accompanying a fold and a back thrust (Fig. 1). Although there are plenty of outcrops the fault system, few subsurface structures were known. This study reconstructs the subsurface structure of the fault system in the Tsaotun area via electric resistivity imaging.

\section{METHOD}

This study applied electric resistivity image profiling (RIP) technique with the pole-pole

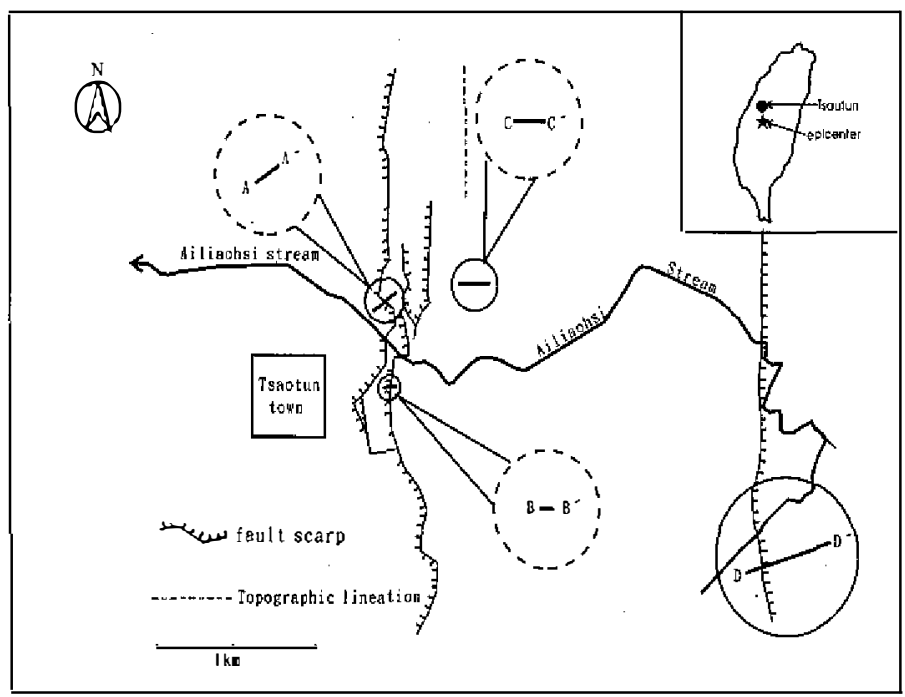

Fig. 1. Surface ruptures along the Chelungpu fault and the back thrust during the 1999 Chi-Chi earthquake, and the locations of the geoelectric profiles A$\mathrm{A}^{\prime}, \mathrm{B}-\mathrm{B}^{\prime}, \mathrm{C}-\mathrm{C}^{\prime}$, and D-D', in the Tsaotun area. 
electrode array because it has a high data density for high resolution interpretation. The polepole array is a four-electrode configuration with one current electrode and one potential electrode, called the sounding electrodes, are set on the surface of the profile to be investigated, while the other two electrodes including one current electrode and one potential electrode, called the remote electrodes, are fixed at distant places. The remote electrodes are not only far from the profile but also far from each other (Fig. 2a). In the field, a number of electrodes were arranged on the surface of the profile with equal intervals to enable automatic changing of the sounding electrodes (Fig. 2b)(Cheng 2000).

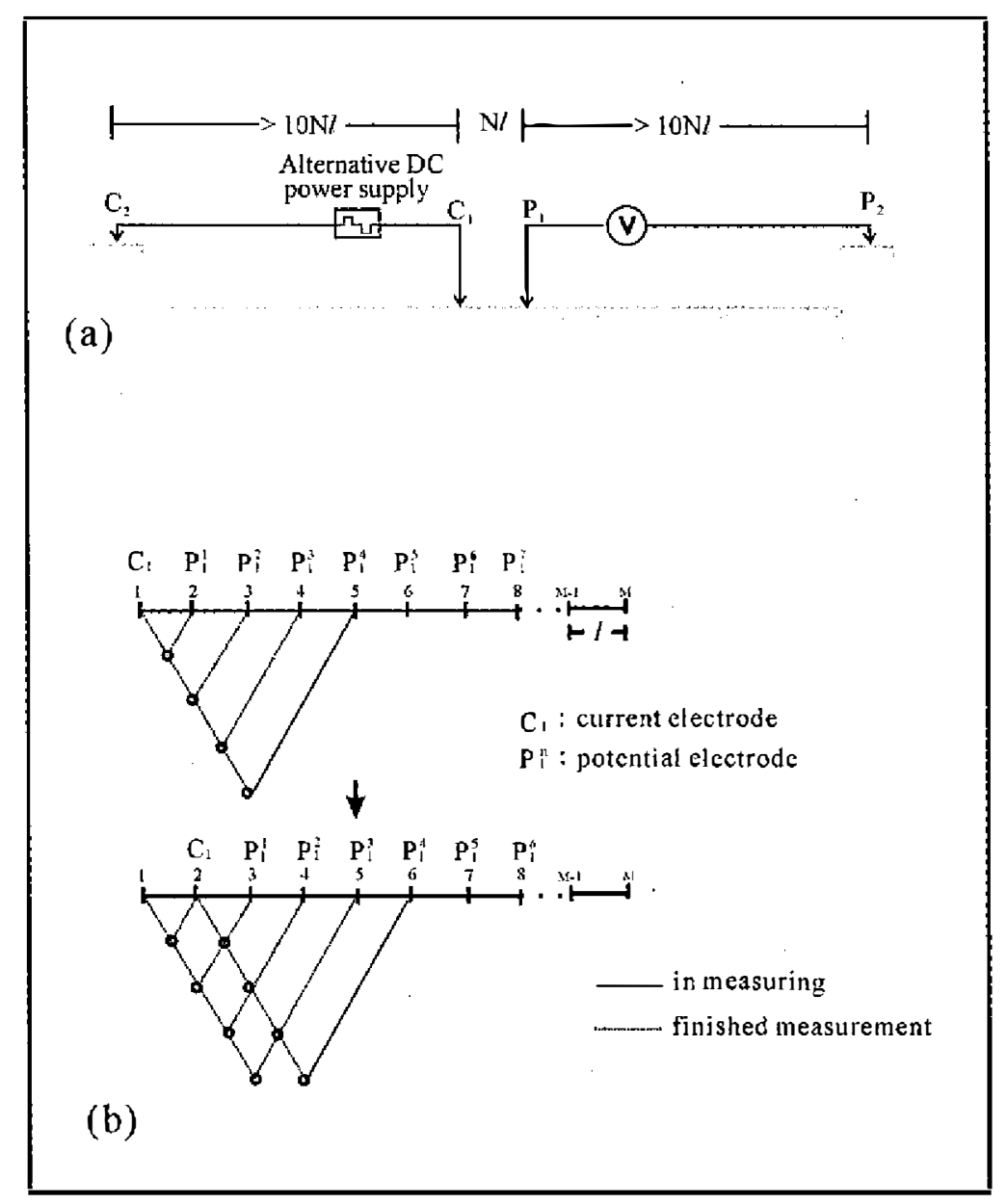

Fig. 2. Electrode configuration of the pole-pole array used in RIP. (a) The sounding electrodes $C_{1}$ and $P_{1}$ are arranged on the surface of the profile to be investigated. They have a electrode-spacing varying from $l$ to $\mathrm{N} l$. The remote electrodes $\mathrm{C}_{2}$ and $\mathrm{P}_{2}$ are fixed at distant places from the profile. (b) A number of electrodes are arranged on the surface of the profile to enable the automatic changing of the sounding electrodes. 
The RIP data set is usually displayed as apparent resistivity pseudosection, as each apparent resistivity is plotted at the mid-point of the sounding electrodes, which serves as the abscissa, while the sounding electrode-spacing serves as the ordinate (pseudodepth). Theoretically, the depth of the investigation is proportional to the electrode-spacing. Hence, the apparent resistivities for shorter electrode-spacings are responses of shallow strata, those of the larger electrode-spacings are responses of deeper strata. An apparent resistivity pseudosection looks like an image of bulk resistivity distribution of the formations. The apparent resistivity is not the true resistivity at the place, but rather an equivalent resistivity of the formations in the electrode geometry. The true resistivity of the strata can be obtained with proper interpretation.

The RIP data were interpreted by the 2-D inversion method since a fault can be regarded as a 2-D structure. The forward part of the 2-D inversion program used in this study is based on the finite element method ,and the inverse part is based on the least-squares optimization technique (deGroot-Hedlin and Constable, 1990; Loke and Barker 1996; Tong and Yang 1990).

\section{RESULTS AND DISCUSSIONS}

Four RIP data sets of A-A', B-B', C-C', and D-D' profiles were obtained in the Tsaotun area (Fig. 1).

\subsection{Profile A-A'}

Profile A-A' is located on the northern side of the Ailiaohsi stream, northeast of Tsaotun (Fig. 1). The $\mathrm{N}^{\circ} 5^{\circ} \mathrm{E}$ trending Profile A-A' consists of 32 sounding electrodes with total length of $186 \mathrm{~m}$ distributing on a partly flat and partly sloping ground surface (Fig. 1), This profile

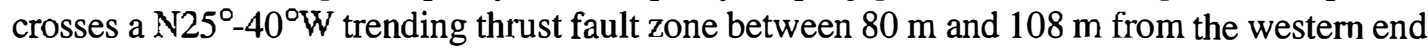
(point A, Fig. 1). The hanging wall outcrops beside the Ailiaohsi stream indicated that the strata contain top soil $(1 \mathrm{~m})$, gravel bed $(10 \mathrm{~m})$, and shale in descending order.

Figure 3 shows the measured apparent resistivity pseudosection and the interpretative results of Profile A-A'. The root mean square relative (RMS) error between the measured and calculated apparent resistivities is very small (2.5\%, Fig. 3) implying these interpretative results are good .According to Fig. 3 the formations can be divided into two blocks from the middle as the western block contains a higher resistivity of 240-2600 $\Omega-\mathrm{m}$, and the eastern block contains a lower resistivity of 9-240 $\Omega$-m except the top layer. The western block can be further divided into two parts, i.e., the upper part has a resistivity of 600-2600 $\Omega$-m (layer $\mathrm{G}$ in Fig. 3), and the lower part has a resistivity of 240-600 $\Omega$-m (layer $G_{1}$ in Fig. 3). The top layer of the eastem block has a resistivity of 600-1600 $\Omega-\mathrm{m}$ (layer $\mathrm{G}$ in Fig. 3), and the botton layer has a low resistivity of 9-35 $\Omega$-m (layer $S$ in Fig. 3). A transition zone with resistivity of 35-240 $\Omega$-m exists between the western block and the eastern basal layer (layer T in Fig. 3). Although their resistivities are equivalent for top layers of eastern and western blocks, the top layer of the eastern block is about $12 \mathrm{~m}$ thick, but the upper part of the western block is about $40 \mathrm{~m}$ thick.

Resistivity measurements on outcrops indicate that the terrace gravel bed has a resistivity of 500-2500 $\Omega-\mathrm{m}, 70-300 \Omega-\mathrm{m}$ for the Toukoshan Formation and 8-35 $\Omega-\mathrm{m}$ for the Chinshui 

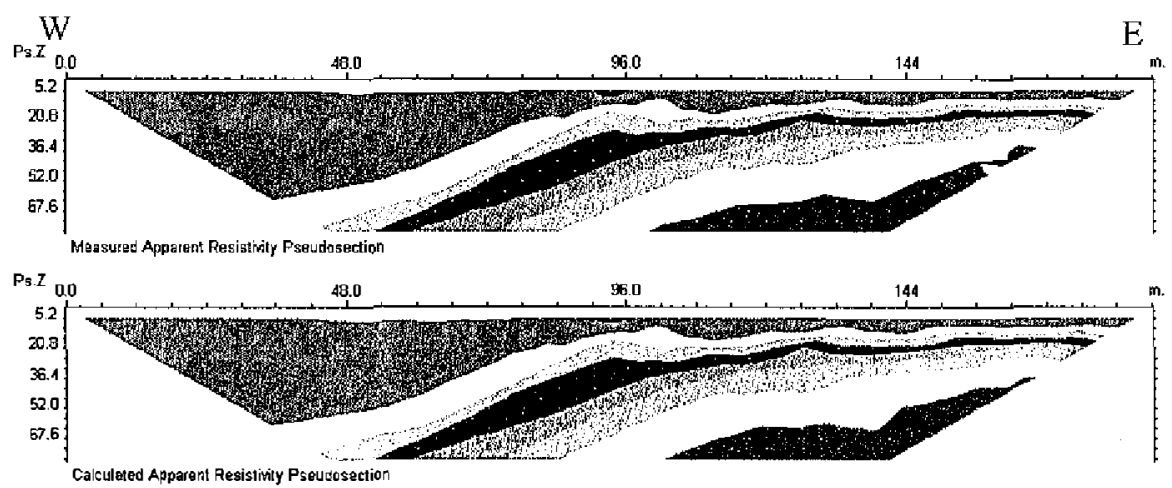

Maxtel Resistivity will, 'liopugraphy

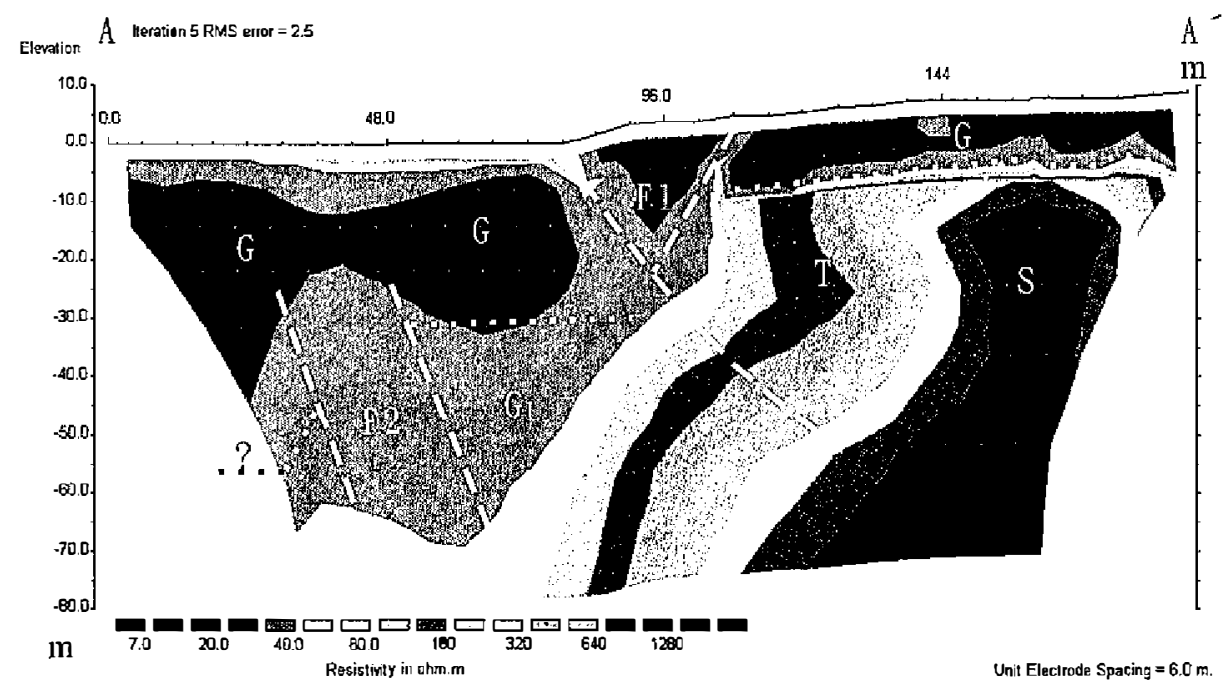

Horizortal scale is 29.71 pixels per uni spacing

Vetical exaggeration in model section display $=1.00$

First electrode is localed at $00 \mathrm{~m}$.

Last olectrodo is locoled at $180.0 \mathrm{~m}$.

Fig. 3. Measured apparent resistivity pseudosection and the interpretative results of Profile A-A' Top: the measured apparent resistivity pseudosection; middle: the calculated apparent resistivity pseudosection; and bottom: the interpretative model derived from the measured data. $F_{1}$ and $\mathrm{F}_{2}$ are resistivity-layer discontinuities, they are the fault zones of the Chelungpu fault. The resistivity-layers and their correlated formations are $\mathrm{G}$ : terrace gravel bed, $\mathrm{G}_{1}$ : Toukoshan $\mathrm{F}$., $\mathrm{T}$ : mixture of gravel, mud, and shale, S: Chinshui Shale.

shale. Comparing the strata appeared in the fault zone outcrop beside the Ailiaohsi stream with different resistivity-layers, we correlate the high resistivity top layer to the terrace gravel bed, the transition zone to a mixture of gravel and mud, and the the low resistivity basal layer of the 
eastern block to the Chinshui Shale. As for the western block, the high resistivity upper part and the moderate resistivity lower part are correlated to the terrace gravel bed and the Toukoshan Formation, respectively.

Two discontinuities labeled as $\mathrm{F}_{1}$ and $\mathrm{F}_{2}$ on resistivity layers are found in Profile A-A (Fig. 3). The discontinuity $\mathrm{F}_{1}$ is characterized by a $\mathrm{V}$-shape relative low resistivity zone (320$480 \Omega-\mathrm{m})$ within the high resistivity top layer $(600-1600 \Omega-\mathrm{m})$ between $78 \mathrm{~m}$ and $110 \mathrm{~m}$ from point $\mathrm{A}$, where is the front of the terrace slope. The high resistivity top layer is about 40 $\mathrm{m}$ and $12 \mathrm{~m}$ thick on the western and the eastern sides of $F_{1}$, respectively. The western branch of the V-shape discontinuity dips eastwardly at an angle of about $70^{\circ}$. Oppositely, the eastem branch dips westwardly at an angle of about $60^{\circ}$. The locations of these branches correspond to a major rupture of $2 \mathrm{~m}$ in throw and a large fracture formed during the $1999 \mathrm{Chi}$-Chi earthquake, suggesting that $F_{1}$ is a fault zone induce by the Chi-Chi earthquake and earlier events. The base of the high resistivity top layer on the eastern side of $F_{1}$ is about $30 \mathrm{~m}$ higher than that on the western side. This indicates that $F_{1}$ is a thrust fault resulted from several thrusting events since the top layer was deposited. The top layer also exhibits an elevation difference of about $10 \mathrm{~m}$ on the surface across the fault zone implying that the fault has been active recently. The $\mathrm{V}$-shape discontinuity $F_{1}$ is followed by a sequence of distortion on isoresistivity contours in the transition zone, which extend to the low resistivity basal layer to the east at an angle of about $60^{\circ}-30^{\circ}$ further indicated that $F_{1}$ is a thrust fault.

The discontinuity $F_{2}$ is about $60 \mathrm{~m}$ west of $F_{1}$ and $30 \mathrm{~m}$ from point $A$. It has a step-like resistivity structure on the base of the high resistivity top layer. The base of the top layer on the eastern side of $\mathrm{F}_{2}$ is about $15 \mathrm{~m}$ higher than that on the western side, but there is no elevation difference between both sides on the ground. It implies that the discontinuity $F_{2}$ is a fault formed by previous activities but was not active during the Chi-Chi earthquake. The discontinuity $\mathrm{F}_{2}$ dips eastwardly at an angle of about $70^{\circ}$ at the depth of $40 \mathrm{~m}$ and plunges into the base of the low resistivity basal layer on the east. It indicates that the deep portion of $F_{2}$ is the boundary between the Toukoshan Formation on the footwall (west) and the Chinshui Shale on the hanging wall (east).

\subsection{Profile B-B'}

The $\mathrm{N} 85^{\circ} \mathrm{E}$ trending Profile B-B' is $93 \mathrm{~m}$ in length distributing across a step-like surface on the southern side of the Ailiaohsi stream, east of Tsaotun town (Fig. 1). It consists of 32 sounding electrodes with $3 \mathrm{~m}$ of intervals. It cuts perpendicularly through a fault scarp of 2.5 $\mathrm{m}$ in height 12-15 $\mathrm{m}$ from the westem end of the profile (point B, Fig. 1). Before the 1999 ChiChi earthquake, the fault scarp was hardly recognized as its short apparent length of about 20 $\mathrm{m}$ and small vertical displacement of $2 \mathrm{~m}$.

Figure 4 illustrates the measured apparent resistivity pseudosection and the interpretative results. The apparent resistivities are about 300-1000 $\Omega-\mathrm{m}$ mostly on the top of the pseudosection and decrease downward rapidly to less than $20 \Omega$-m below the pseudodepth of $21 \mathrm{~m}$ (Fig. 4). It implies that the earth consists of a thin top layer of high resistivity and a basal layer of low resistivity. Fig. 4 shows that the interpretative results have a moderate RMS error $(5.9 \%)$ indicating a good fitness between the observed and calculated data. The interpretative 

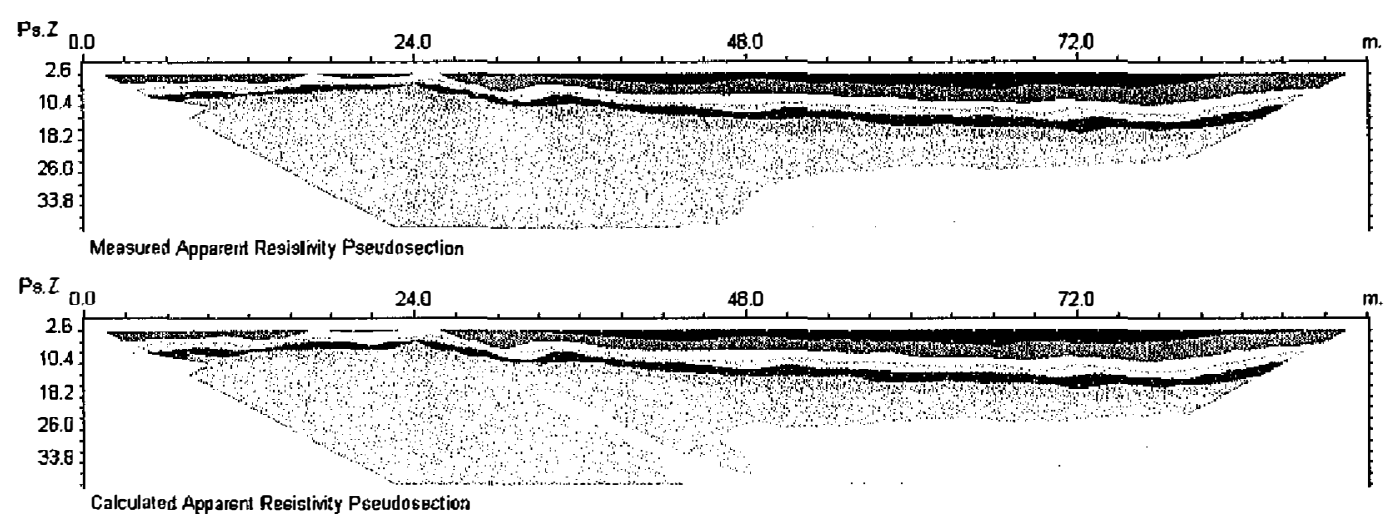

Calculated Apparent Resistivity Pseudosbction

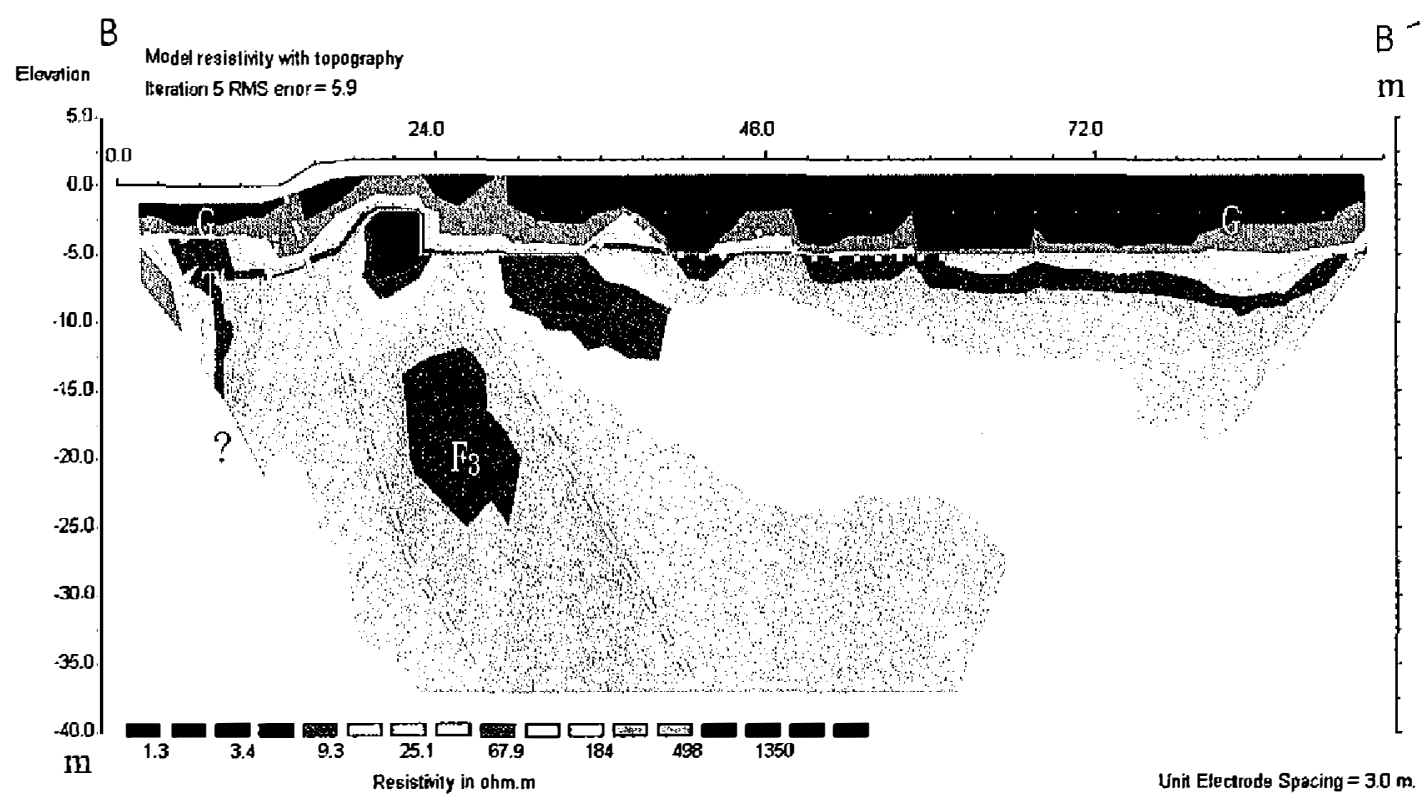

Hosizontal scale is 29.71 pixels per unit spacing

Vettical exaggeration in model section display $=1.00$

First eleclrode is located at $0.0 \mathrm{~m}$.

Last electrode is located at $93.0 \mathrm{~m}$.

Fig. 4. Measured apparent resistivity pseudosection and the interpretative results of Profile B-B'. Top: the measured apparent resistivity pseudosection; middle: the calculated apparent resistivity pseudosection; and bottom: the interpretative model derived from the measured data. The high resistivity eastdipping zone, $\mathrm{F}_{3}$, is the fault zone of the Chelungpu fault. The resistivity-layers and their correlated formations are G: terrace gravel bed, S: Chinshui Shale, T: mixture of soil, gravel and shale. 
results (Fig. 4) indicate that the formation can be divided into two layers of the top layer and the basal layer by different resistivity. The top layer (layer $G$ in Fig. 4) has a resistivity of 600$2600 \Omega-\mathrm{m}$ and is about 3-7 $\mathrm{m}$ thick. Its thinnest part coincides with the fault zone located between $15 \mathrm{~m}$ and $24 \mathrm{~m}$ from point B. The basal layer (layer S in Fig. 4) consists of a eastdipping zone ( $\mathrm{F}_{3}$, Fig. 4) with resistivity of 22-65 $\Omega-\mathrm{m}$ and a background formation with resistivity of 8-22 $\Omega-\mathrm{m}$. The eastdipping zone, $\mathrm{F}_{3}$, is about $10-25 \mathrm{~m}$ wide embedded in the background formation and is connected with the fault zone on the ground surface suggesting that $\mathrm{F}_{3}$ is a subsurface fault zone. The top of the basal layer on the eastern side of $F_{3}$ is about $23 \mathrm{~m}$ higher than that on the western side. It implies that $\mathrm{F}_{3}$ had moved several times before the 1999 Chi Chi earthquake. The fault zone dips eastwardly at an angle of about $80^{\circ}-60^{\circ}$ and decreases with depth from the ground surface to a depth of $40 \mathrm{~m}$. The strata between depths of $4 \mathrm{~m}$ and $20 \mathrm{~m}$ at the western end of the profile have a resistivity of 35-1000 $\Omega-\mathrm{m}$ showing a contrast to the basal layer which has a resistivity of $8-22 \Omega-\mathrm{m}$. These strata are thought to be a mixture of soil, gravel and shale which collapsed from the hanging wall.

\subsection{Profile C-C'}

The $\mathrm{N} 83^{\circ} \mathrm{E}$ trending Profile C-C is $252 \mathrm{~m}$ long and crosses the south extension line of a $\mathrm{N}-\mathrm{S}$ trending topographic lineation $500 \mathrm{~m}$ to the north at about $1 \mathrm{~km}$ northeast of Tsaotun town (Fig. 1). It consists of 64 sounding electrodes with $4 \mathrm{~m}$ of intervals on a leveled surface. The measuring was conducted on July 26,1999, about 2 months prior to the 1999 Chi-Chi earthquake, for the detectation of the Chelungpu fault.

Figure 5 shows the measured data and the interpretative results. A moderate RMS error of 6.1\%(Fig. 5) according to the interpretative results indicated a good fitness between the observed and calculated data. Like previous profiles, we divided the earth into two layers of the top layer and the basal layer based on different resistivity. The top layer has a resistivity of 500-1000 $\Omega$-m (layer G in Fig. 5) and can be recognized as the Quaternary terrace gravel bed. The basal layer has a resistivity of 12-60 $\Omega$-m mainly (layer $S$ in Fig. 5), and can be correlated to the Pliocene Chinshui Shale. The unconformable contact of these two formations appeared on the cliff and river bed of the Ailiaohsi stream south of the profile. Figure 5 shows that the top layer has a thickness of about 10-15 m, and no obvious vertical offset on its base except a notch arround $64 \mathrm{~m}$ from the western end of the profile. The strata are undisturbed except a small fracture-like high resistivity structure. This indicates no obvious vertical displacements occurred there. We suggests that there is no fault beneath the profile, and the topographic lineation existing to the north of profile is not a fault structure. This was further confirmed by absence of fault zone and distinguishable deformation during Chi-Chi earthquake.

\subsection{Profile D-D'}

Profile D-D is situated at about $3 \mathrm{~km}$ east of Tsaotun town. It consists of 64 sounding electrodes with $10 \mathrm{~m}$ of intervals spreading along $N 73^{\circ} \mathrm{E}$ direction (Fig. 1). The profile is 630 $\mathrm{m}$ long and crosses a $\mathrm{N} 10^{\circ} \mathrm{W}$ trending scarp of about $4.2 \mathrm{~m}$ of height at $150-160 \mathrm{~m}$ from the western end of the profile (point D, Fig. 1). The 1999 Chi-Chi earthquake induced an addi- 

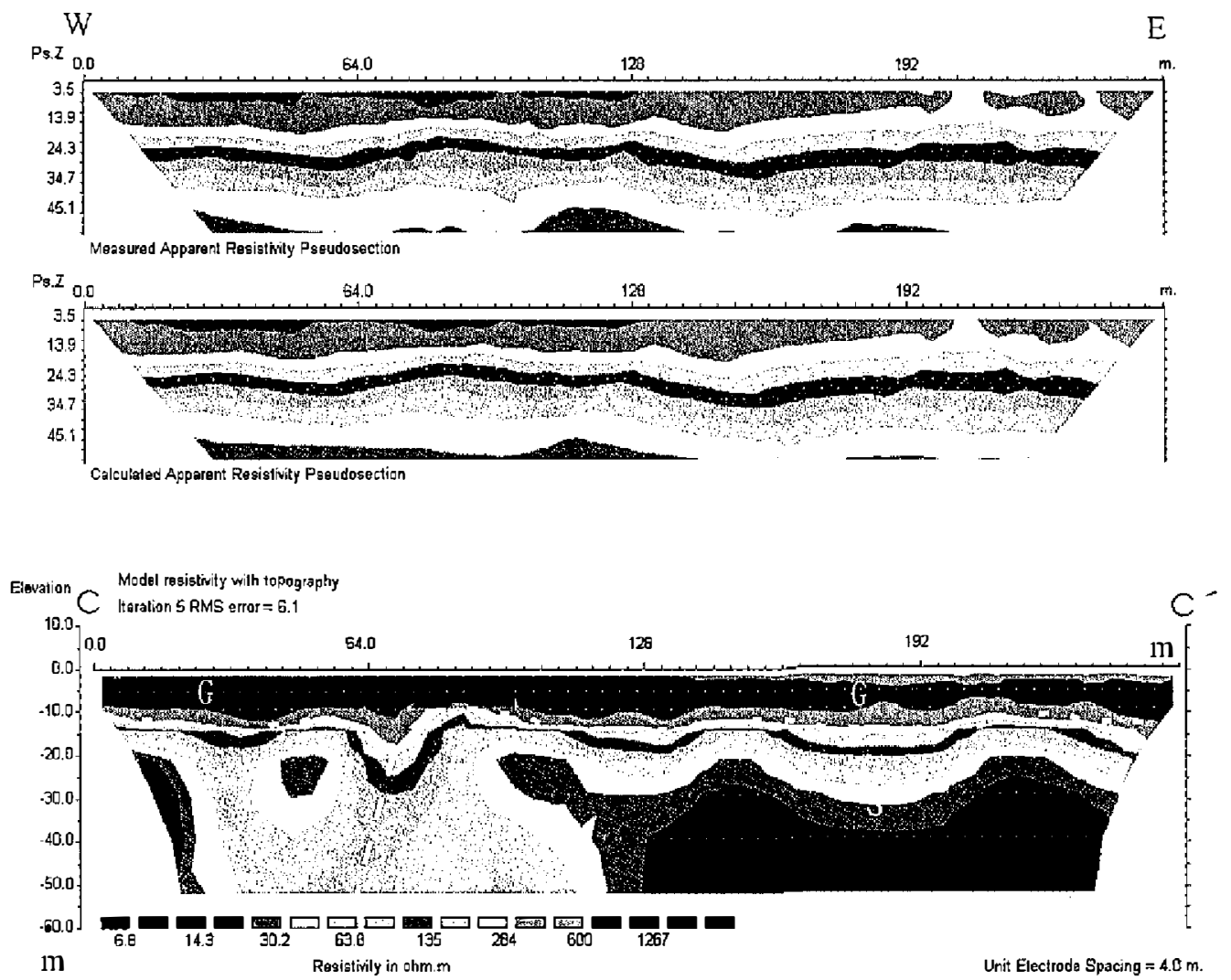

Hoizontal scale is 14.62 pixels per unit spacing

Vertical exaggeration in model section dieplay $=1.00$

First electrode is localed at $0.0 \mathrm{~m}$.

Last electrode is located al $2520 \mathrm{~m}$

Fig. 5. Measured apparent resistivity pseudosection and the interpretative results of Profile C-C'. Top: the measured apparent resistivity pseudosection; middle: the calculated apparent resistivity pseudosection; and bottom: the interpretative model derived from the measured data. No vertical offset present in the profile before the 1999 Chi-Chi earthquake. The resistivity-layers and their correlated formations are G: terrace gravel bed, S: Chinshui Shale.

tional height of about $0.2 \mathrm{~m}$ on the preexisting scarp $(4 \mathrm{~m})$ and several fractures between 160 $\mathrm{m}$ and $480 \mathrm{~m}$ from point $\mathrm{D}$ indicating it is a fault scarp.

The measured data and the interpretative results are shown in Fig. 6. The measured apparent resistivity pseudosection shows that the apparent resistivities are about 80-150 $\Omega-\mathrm{m}$ at the top of the pseudosection and decrease with pseudodepth to about 10-20 $\Omega$-m at the bottom. It implies that the earth has a higher resistivity in the shallow part than the deeper portion. It also exhibits a lateral variation beneath the location of $140-160 \mathrm{~m}$ from point $\mathrm{D}$ implying a resistivity-layer discontinuity exists around there. Figure 6 shows that the interpretative results have a 

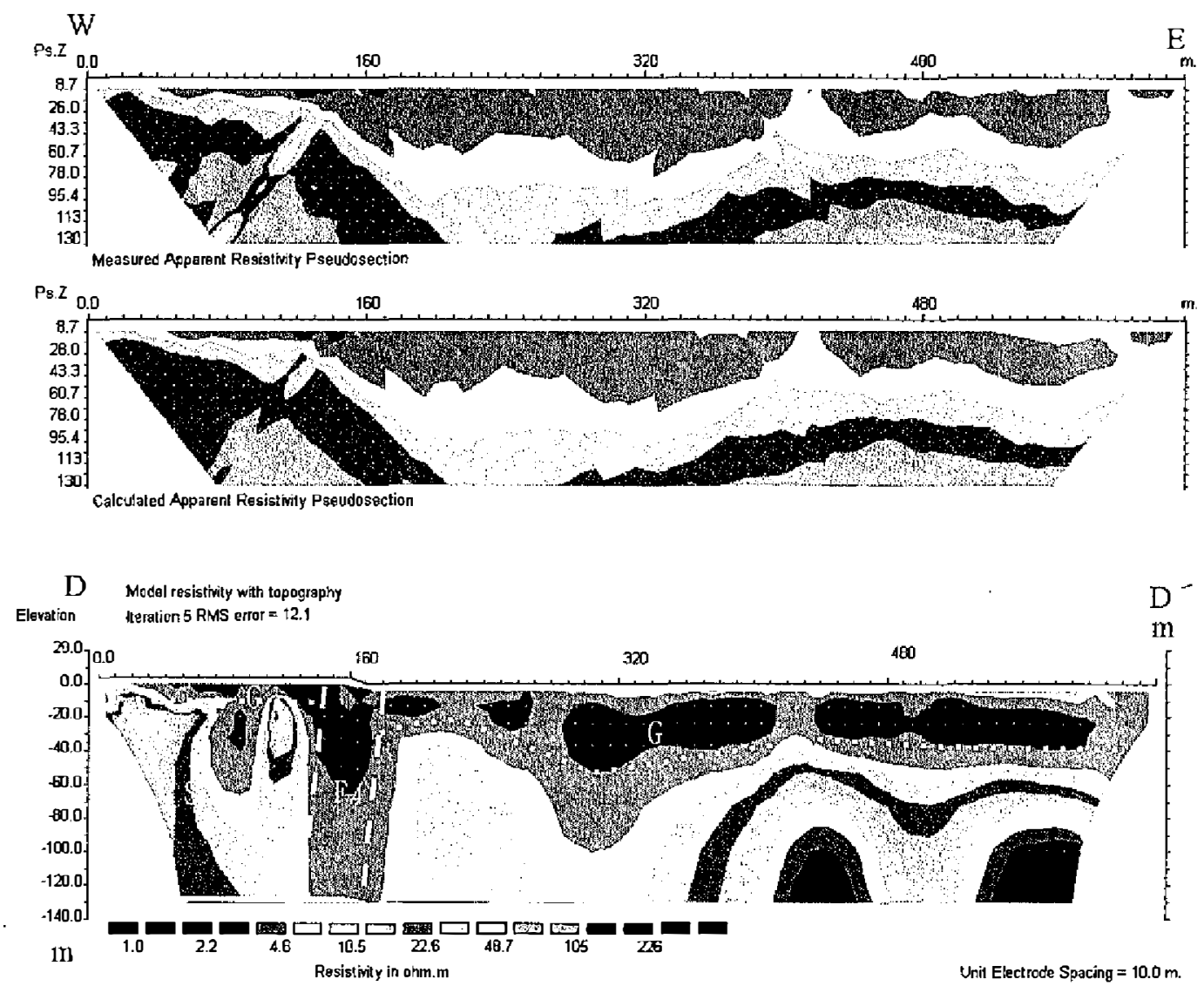

Horizontal scale is 14.62 pixels per unit spacine

Vertical exaggeration in model section display $=1.00$

First electrode is located at $0.8 \mathrm{~m}$.

Last electrode is located al $630.0 \mathrm{~m}$.

Fig. 6. Measured apparent resistivity pseudosection and the interpretative results of Profile D-D'. Top: the measured apparent resistivity pseudosection; middle: the calculated apparent resistivity pseudosection; and bottom: the interpretative model derived from the measure data. The high angle westward dipping resistivity zone, $F_{4}$ is a back thrust of the Chelungpu fault. The resistivity-layers and their correlated formations are G: terrace gravel bed, $S_{1}$ : Cholan F.

RMS error of $12.1 \%$. This slightly higher error is due to contaminated data caused by nearby high-tension power lines. The fitness is not as good as the other profiles, but the interpretative results are acceptable because the main characteristics of the measured data are present on it. The interpretative results (Fig. 6) indicate that the formations can be divided into two layers, i.e., the top layer has a resistivity of 100-250 $\Omega$-m (layer $\mathrm{G}$ in Fig. 6) and the basal layer has a resistivity of 10-50 $\Omega-\mathrm{m}$ (layer $\mathrm{S}_{1}$ in Fig. 6). The former and the latter can be correlated to 
the Quaternary gravel bed and the sandstone of the Cholan Formation, respectively. They appear on the river bed and cliff near the profile.

The interpretative results illustrate the presence of a resistivity-layer discontinuity, $F_{4}$, between $130 \mathrm{~m}$ and $180 \mathrm{~m}$ from the western end of the profile as the strata have a resistivity of 50-500 $\Omega$-m (Fig. 6). It further separates the top layer into two parts of different thickness, i.e., the eastern part is about $40 \mathrm{~m}$ thick and the western part is about $10 \mathrm{~m}$ thick. The location of $\mathrm{F}_{4}$ coinsides with the fault scarp partially formed during the 1999 Chi-Chi earthquake indicating that the resistivity-layer discontinuity is the subsurface fault zone. Figure 6 shows that the base of the top layer on the western side of $\mathrm{F}_{4}$ is about $30 \mathrm{~m}$ higher than that on the eastern side implying that the western block has been lifted about $30 \mathrm{~m}$ relative to the eastern block post deposition of the terrace gravel bed. Figure 6 also shows that $F_{4}$ dips westwardly at an angle of about $80^{\circ}$ indicating that it is a reverse fault.

\section{CONCLUSIONS}

Several conclusions can be drawn from the electric study.

(1) The strata around the Chelungpu fault can be divided into three units: the top layer, the eastern basal layer, and the western basal layer, with resistivity. The top layer has a resistivity of $600-2600 \Omega-\mathrm{m}$ and a thickness of $10-16 \mathrm{~m}$ on the east and $30-60 \mathrm{~m}$ west of the Chelungpu fault. The eastern and the western basal layers have resistivities of 8-35 $\Omega-\mathrm{m}$ and 80-240 $\Omega-\mathrm{m}$, respectively. These resistivity units can be correlated to the Quaternary terrace gravel bed covered with soil, the Chinshui Shale, and the Toukoshan Formation, respectively.

(2) The electric resistivity structures interpreted from the RIP data fit well with the fractures and outcroping strata. The resistivity-layer discontinuities found in the RIP profiles correlated to fault zones formed during the 1999 Chi-Chi earthquake and former events as the subsurface structures of faults.

(3) The Chelungpu fault is a reverse fault including several fracture zones in the Tsaotun area. Ruptures not only developed in weak layers of the Chinshui Shale but also along the characteristic boundary between the Toukoshan Formation on the footwall and the Chinshui Shale on the hanging wall. The main fracture zones have a width of 6-40 m, dip eastward at an angle of $80^{\circ}-30^{\circ}$ that decreases with depth. At some places, the fault zone diverged into $\mathrm{V}$. shape fractures or more branches near the ground surface.

(4) Not all the fault zones of the Chelungpu fault moved during the 1999 Chi-Chi earthquake. The fault zone $\mathrm{F}_{2}$ found in Profile A- $\mathrm{A}$ ' is a characteristic boundary of the Chelungpu fault with no significant rupture on the surface nor the subsurface during the 1999 Chi-Chi earthquake.

(5) The scarp about $3 \mathrm{~km}$ east of Tsaotun town is a fault scarp of the back thrust of the Chelungpu fault. The back thrust dips westwardly at an angle of about $80^{\circ}$ in the shallow part with the Quaternary terrace gravel bed and the Pleiocene Cholan Formation on both sides of the fault plane. The terrace gravel bed has a resistivity of $100-250 \Omega$-m and is $20-50 \mathrm{~m}$ thick on the 
east, but is $10-13 \mathrm{~m}$ thick west of the fault plane. The Cholan Formation in the Tsaotun area has a resistivity of $10-50 \Omega-\mathrm{m}$.

(6) The N-S trending topographic lineation $1.5 \mathrm{~km}$ northeast of the Tsaotun town may not be a fault because no resistivity structures of fault is present beneath its south extension profile. Further more, neither surface rupture nor distinguishable deformation was observed after the Chi-Chi earthquake.

Acknowledgement The authors are grateful to the diligent field crew of the Geoelectric Group at the Institute of Geophysics, National Central University. This study is supported by the National Science Council of Taiwan under the grant (NSC89-2921-M-008-014-EAF) entitled "Investigation of the 921 Chi-Chi Earthquake".

\section{REFERENCES}

Chang, H. C., C. W. Lin, M. M. Chen, and S. T. Lu, 1998: An introduction to the active faults of Taiwan, Central Geological Survey, MOEA., ROC, Taiwan,103pp.(in Chinese)

Chang, H. C., C. W. Lin, and S. T. Lu, 1999: The report of a field survey of the 921 earthquake, Central Geological Survey, MOEA., ROC, Taiwan, (in Chinese)

Chang, S. L., 1971: Subsurface geologic study of the Taichung basin. Petrol. Geol. Taiwan, 8, 21-45.

Cheng, P. H. 2000: Imaging the subsurface structure of the northern tip of the 1999 Chi-Chi earthquake fault in central Taiwan using the electric resistivity method. TAO, 11, 721734.

deGroot-Hedlin, C., and S. Constable, 1990: Occam's inversion to generate smooth, twodimensional models from magnetotelluric data. Geophysics, 55, 1613-1624.

Lee, J. F., C. S. Hou, C. C. Lin, and T. C. Lai, 1999: The Chelungpu fault and the 921 Chi-Chi large earthquake. Special issue of the Chi-Chi large earthquake, Central Weather Bureau and the Geophysical Soc. of China, Taiwan, 7-36. (in Chinese)

Lin, C. C., 1957: Topography of Taiwan, Historical Research Commission of Taiwan Province, Taiwan, 423pp. (in Chinese)

Lin, C. W., H. C. Chang, S. T. Lu, T. S. Shin, and W. J. Huang, 2000: An introduction to the active faults of Taiwan, 2nd ed., Central Geological Survey, MOEA., ROC, Taiwan, 122pp. (in chinese)

Loke, M. H., and R. D. Barker, 1996: Rapid least-squares inversion of apparent resistivity pseudosection by a quasi-Newton method. Geophys. Prosp., 44,131-152.

Meng, C. Y., 1963: San-I overthrust. Petrol. Geol. Taiwan, 2, 1-20.

Pan, Y. S., 1967: Interpretation and seismic coordination of the Bouguer gravity anomalies overwest-central Taiwan. Petrol. Geol. Taiwan, 4, 287-301.

Tong, L. T., and C. H. Yang, 1990: Incorporation of topography into two-dimensional resistivity inversion. Geophysics, 55, 354-361. 